\title{
Hwang's fraud adds impetus to ES cell research
}

\section{To the editor:}

Your editorial in the January issue (Nat. Biotechnol. 24, 1, 2006) states that the fabrication and falsification of data by Woo Suk Hwang is "a setback for the field," but "has little bearing on the therapeutic potential of ES cells or on the value of research being done elsewhere." I concur with this view. The retraction of Hwang's findings ${ }^{1}$ should not compromise the multiple, ongoing or nascent research projects using human embryonic stem (hES) cells around the world or the potential of hES cells as a patient-specific therapy. For those of us who are, or will shortly become, involved in human somatic cell nuclear transfer and embryonic stem (NTES) cell research, reconsidering our work because of a hoax

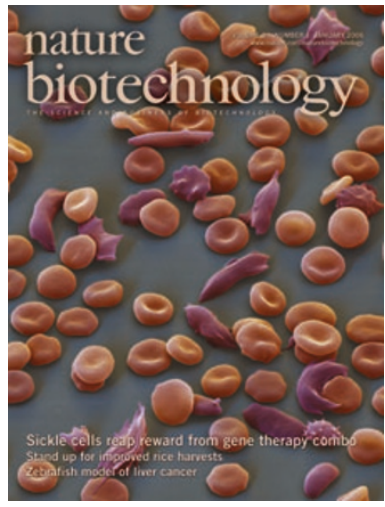
in our field is unthinkable.

Although many of the results of Hwang's experiments were falsified, in fact there is good reason to conclude that the human NTES cell method exploited by his team ultimately will prove an effective means of producing patient-specific NTES cells. Thus far, there have been successful reports of NTES cell derivation from mice ${ }^{2}$ and cattle ${ }^{3}$, and there are encouraging indications that a similar approach can be used with human cells.

Researchers in the United Kingdom have reported cloned blastocysts using undifferentiated cells from a hES cell line as the nuclear donor ${ }^{4}$. Because it is difficult to obtain high-quality human eggs for nuclear transfer, Huizhen Sheng and her group in Shanghai, China fused human somatic cell fibroblasts obtained from foreskin or the face of patients undergoing surgery into enucleated rabbit oocytes, producing 158 blastocysts out of 1,086 electrofused oocytes-donor cells ${ }^{5}$. In this study, they compared and found no difference among human cell nuclear donors at ages of 5, 42, 52 and 60 years in blastocyst development of cloned 'hybrid' embryos and several NTES cell lines were derived from each of the four age groups.

In the absence of what we believed to be a milestone paper in the field, we are now ready to tackle the problem of deriving hES cell lines for specific patients. In the

\section{To the editor:}

Surveys of public attitudes to biotech in advanced societies rely on analyses of representative population samples and of media coverage. A common conclusion from these analyses is that the public is strongly opposed to biotech applications in food and agriculture ('green biotech') but less opposed (or more ambivalent) to applications in biomedicine ('red biotech'). In no region is this truer than in Europe, where the prevailing assumption of scientists and policymakers is that the public is generally antagonistic to biotech.

Building on recent lines of research ${ }^{1-3}$, we present here a re-evaluation of data from the latest Eurobarometer survey of European public attitudes to biotech ${ }^{4}$. Our analysis suggests that the goal of improving
United States, several states have enacted legislation that specifically permits research on hES cells created from donated embryos or unfertilized oocytes by somatic cell nuclear transfer. Although it is nearly impossible to control for the kind of fraud perpetrated by Hwang, in the United States such research is under close scrutiny from institutional review boards (IRBs), ES cell research oversight (ESCRO) committees and often university or state regulators.

Another reason why the situation in South Korea is not likely to be replicated in other research settings is that 'rock star' status that Hwang seems to have enjoyed in Korea is not accorded to researchers in other countries, such as the United States or Europe. Hwang's power and

allegations about its national hero. This is not likely to happen in the United States and Europe, where there are historical precedents for whistleblowing and where no scientist is considered a cultural icon comparable to Hwang.

ES cell science is sound, the opportunities are great, and the controls, both societal and governmental, are in place. I expect that the breakthroughs Hwang wanted to claim as his own will soon be someone else's. I believe strongly that the Hwang affair is an individual case of the sort that can happen in any field of science. It is to be hoped that these events will not unduly affect future related ES cell research in Korea, Asia the West or the rest of the world.

\section{Xiangzhong Yang}

Center for Regenerative Biology, University of Connecticut, 1392 Storrs Rd., Unit 4243, Storrs, Connecticut 06269-4243, USA

e-mail: xiangzhong.yang@uconn.edu influence were so great that his colleagues were unwilling to speak up, although they were aware that there were problems. And even after allegations became public, because the Korean scientific culture does not encourage whistleblowers, the country as a whole seemed reluctant to believe the
1. Kennedy, D. Science, published online 12 January 2006 (doi: 10.1126/science.1124926, accessed 12 January 2006).

2. Wakayama, T., Rodriguez, I., Perry, A.C., Yanagimachi, R. \& Mombaerts, P. Proc. Natl. Acad Sci. USA 96

3. Wang, L. et al. Biol. Reprod. 73, 149-155 (2005).

4. Stojkovic, M. et al. Reprod. BioMed. Online 11, 226-231 (2005)

5. Chen, Y. et al. Cell Res. 13, 251-263 (2003). 14984-14989 (1999).

\section{Are Europeans really antagonistic to biotech?}

acceptance of biotech should be addressed not only by dialogue and participation, but also by informing the public more about each new specific application, explaining the associated benefits and providing some basic notions of the science involved.

Question Q12.1 of the latest Eurobarometer survey seeks to measure Europeans' attitudes toward six biotech applications using the 'split-half' technique (half the sample were asked about genetic testing, xenotransplantation, and engineering food quality or attributes, and the other half about insect-resistant transgenic crops, recombinant enzymes for use in household products, and therapies based on human cells that have undergone somatic cell nuclear transfer (therapeutic cloning); for full wording 